\title{
EKSPLORASI BAKTERI ANTAGONIS ASAL JARINGAN DAN RIZOSFER TANAMAN KARET UNTUK MENEKAN PERTUMBUHAN BAKTERI PROTEOLITIK PADA BAHAN OLAHAN KARET (BOKAR)
}

\section{Antagonistic Bacteria Exploration from Rubber Plant Tissue and Rhizosfer to Suppress the Growth of Proteolitic Bacteria from Slab}

\author{
Nuni Gofar ${ }^{1 *}$, Munawar ${ }^{2)}$, Hary Widjajanti'2), dan Angga Prasetya Mulya ${ }^{1)}$ \\ 1) Program Studi Agroekoteknologi, Fakultas Pertanian Universitas Sriwijaya J1. Raya Palembang-Prabumulih KM \\ 35 Indralaya Ogan Ilir \\ 2) Program Studi Biologi, Fakultas Matematika dan Ilmu Pengetahuan Alam Universitas Sriwijaya Jl. Raya \\ Palembang-Prabumulih KM 35 Indralaya Ogan Ilir
}

\begin{abstract}
Latex is a mainstay of agriculture commodity and one of the most important sources of Indonesia's foreign exchange earnings. However, the latex storage spreads odor to the air. The goal of this research is to explore antagonistic bacteria from rubber plant tissue and rhizosfer. These antagonistic bacteria can suppress the growth of proteolitic microbe that caused odor in rubber slab. The proteolitic bacteria are isolated from various shelf life of rubber slab. Antagonistic bacteria are isolated from rubber plant tissue and rhizosfer. The ability of antagonistic bacteria to suppress the growth of proteolitic bacteria is done through inhibition test in agar nutrient medium (NA). The diameter of clear zone formed is the indication of antagonistic bacteria ability in suppressing proteolitic bacteria activity. From this research, found 2 bacteria isolate that has the potency to be developed as antagonistic bacteria to suppress proteolitic bacteria activity in the storage process. Both of these antagonistic bacteria are isolates $D_{1} U_{1}$ that comes from the leaves of rubber plant, and isolate $A_{2} U_{2}$ that comes from the root of rubber plant. These isolates produce the widest average of inhibition zone with diameter of $11.37 \mathrm{~mm}$ and $11.29 \mathrm{~mm}$.
\end{abstract}

Keywords: Antagonistics bacteria, odor reduction, latex storage

\begin{abstract}
ABSTRAK
Lateks merupakan komoditas pertanian andalan dan merupakan sumber penerimaan devisa negara Indonesia yang cukup penting, namun pada saat penyimpanannya menyumbangkan bau tidak sedap ke udara. Penelitian ini bertujuan untuk mengeksplorasi bakteri antagonis asal jaringan dan rizosfer tanaman karet yang mampu menekan pertumbuhan mikroba proteolitik penyebab bau tidak sedap pada bahan olahan karet (bokar). Bakteri proteolitik penyebab bau tidak sedap diisolasi dari berbagai masa simpan bokar. Bakteri antagonis diisolasi dari jaringan dan rizosfer tanaman karet. Kemampuan bakteri antagonis menekan pertumbuhan bakteri proteolitik dilakukan dengan uji daya hambat dalam medium agar (NA). Diameter zona bening yang terbentuk merupakan indikasi kemampuan bakteri antagonis dalam menghambat aktivitas bakteri proteolitik. Dari hasil penelitian ini diperoleh 2 isolat bakteri yang berpotensi dikembangkan sebagai bakteri antagonis penghambat aktivitas bakteri proteolitik perombak bokar dalam proses penyimpanan. Kedua bakteri antagonis tersebut adalah isolat $\mathrm{D}_{1} \mathrm{U}_{1}$ yang berasal dari daun tanaman karet dan isolat $\mathrm{A}_{2} \mathrm{U}_{2}$ yang berasal dari akar tanaman karet, yang menghasilkan rata-rata zona hambat terluas berturut-turut berdiameter 11.37 dan $11.29 \mathrm{~mm}$.
\end{abstract}

Kata kunci: Bakteri antagonis, penanggulangan bau, bokar

\section{PENDAHULUAN}

Lateks merupakan komoditas pertanian andalan dan merupakan sumber penerimaan devisa negara Indonesia yang cukup penting, sehingga persebaran karet di Indonesia cukup luas $(3,506,201 \mathrm{ha})$ dengan produktivitas 1.45 ton $\mathrm{ha}^{-1}$ (Direktorat Jenderal Perkebunan, 2012). Akan tetapi, dalam proses pengolahannya, lateks yang sudah berbentuk bokar (bahan olahan karet) menimbulkan masalah lingkungan berupa bau yang tidak sedap yang menyebar ke udara. Bau tersebut disebabkan oleh aktivitas mikroba pengurai protein pada lateks yang menghasilkan gas amoniak $\left(\mathrm{NH}_{3}\right)$ dan hidrogen sulfida $\left(\mathrm{H}_{2} \mathrm{~S}\right)$ yang mencemari udara di sekitar pabrik pengolahan bokar. Tercemarnya udara tersebut tentunya akan menurunkan kualitas lingkungan dan mempunyai efek negatif terhadap masyarakat yang berada di sekitar pabrik.

Upaya untuk menghilangkan bau tidak sedap pada penyimpanan bokar sudah banyak dilakukan antara lain dengan menggunakan aroma buah-buahan dan menggunakan asap cair, namun efektivitas dan efisiensinya masih rendah. Suatu teknologi berbasis mikroba dengan mengeksplorasi bakteri antagonis terhadap bakteri proteolitik pengurai protein bokar diharapkan dapat mengatasi penurunan kualitas udara akibat emisi gas amoniak dan hidrogen sulfida. Mikroba 
mempunyai waktu generasi yang cepat dan mempunyai variasi metabolisme yang sangat luas, sehingga mempunyai peluang besar untuk memperoleh mikroba antagonis terhadap mikroba proteolitik penyebab bau tidak sedap bokar dan dapat diproduksi pada skala komersial dengan lebih cepat dan mudah.

Berbagai mikroba menguntungkan seperti pemacu tumbuh, penambat nitrogen, pelarut fosfat, atau perombak hidrokarbon telah banyak ditemukan dari berbagai jaringan dan rizosfer tanaman yang tumbuh pada lahan suboptimal di Sumatera Selatan (Gofar et al., 2012; Munawar et al., 2012; Estuningsih et al., 2012; Elfita et al., 2012; Gofar, 2013). Bakteri endofit termasuk salah satu kelompok mikroba yang memegang peranan penting dalam reaksi ketahanan tanaman terhadap patogen, diantaranya sebagai agens pengendali hayati (Hidayah dan Yulianti, 2008). Bakteri endofitik tanaman karet yang tumbuh liar diduga mampu menghasilkan metabolit sekunder yang bersifat antimikroba terhadap mikroba proteolitik penyebab bau tidak sedap pada bokar. Antagonis mikroba proteolitik asal rizosfer atau jaringan tanaman karet akan dikembangkan sebagai metode penyimpanan bokar baik di tingkat petani maupun di pabrik pengolahan karet. Prinsip kerjanya adalah dengan menekan aktivitas mikroba proteolitik oleh bakteri antagonis yang dapat menghambat penguraian protein bokar (Strobel dan Daisy, 2003).

Berdasarkan uraian diatas, penelitian ini bertujuan untuk mengeksplorasi bakteri antagonis asal jaringan dan rizosfer tanaman karet yang mampu menekan pertumbuhan mikroba proteolitik pada bokar. Penelitian ini akan memberikan kontribusi baru berupa bioteknologi pencegahan bau tidak sedap akibat penguraian protein bokar berbasis mikroba yang bersifat ramah lingkungan.

\section{BAHAN DAN METODE}

Penelitian ini dilaksanakan di Laboratorium Mikrobiologi Jurusan Biologi Fakultas Matematika dan Ilmu Pengetahuan Alam Universitas Sriwijaya Indralaya. Isolat bakteri proteolitik diisolasi dari beberapa sumber, yakni dari lateks yang baru disadap di kebun, bokar simpanan petani, dan bokar di gudang penyimpanan pabrik pengolahan karet. Bakteri antagonis diisolasi dari tanah sekitar rizosfer serta dari jaringan daun dan akar (endofitik) tanaman karet yang tumbuh secara liar di hutan dan sudah tua (berumur lebih kurang 30 tahun) serta tidak pernah dipupuk atau disemprot pestisida.

\section{Isolasi Bakteri Proteolitik}

Sumber bakteri proteolitik berupa lateks yang baru disadap di kebun, bokar simpanan petani, dan bokar di gudang penyimpanan pabrik pengolahan karet dibawa ke laboratorium untuk diisolasi. Lateks dan bokar tersebut masing-masing ditimbang seberat $5 \mathrm{~g}$, dihaluskan, lalu dilakukan pengenceran sampai $10^{-5}$ menggunakan larutan fisiologis steril $0.85 \% \mathrm{NaCl}$. Masing-masing dengan 3 ulangan dari pengenceran $10^{-3}, 10^{-4}$, dan $10^{-5}$ ditumbuhkan pada medium BHMS (Bushnell Hass Mineral Salt) steril dengan komposisi: $0.2 \mathrm{~g} \mathrm{MgSO}_{4} .7 \mathrm{H}_{2} \mathrm{O} ; 0.2 \mathrm{~g} \mathrm{CaCl}_{2} ; 1 \mathrm{~g}$ $\mathrm{KH}_{2} \mathrm{PO}_{4} ; 1 \mathrm{~g} \mathrm{~K}_{2} \mathrm{HPO}_{4} ; 1 \mathrm{~g} \mathrm{NH} \mathrm{NO}_{3} ; 2$ tetes $\mathrm{FeCl}_{3}(60 \%)$; $2 \%$ susu skim dan $1000 \mathrm{~mL}$ akuades dalam cawan petri dengan metode agar tuang, lalu diinkubasikan pada suhu $30^{\circ} \mathrm{C}$ selama 24 jam dalam inkubator.

Tumbuhnya bakteri proteolitik ditunjukkan oleh terbentuknya zona bening di sekeliling koloni bakteri, yang menunjukkan bahwa bakteri tersebut mampu merombak protein asal susu skim pada media. Pertumbuhan bakteri proteolitik diamati dengan menghitung jumlah koloni yang terbentuk dan morfologi koloni. Koloni-koloni yang memiliki zona bening terluas dimurnikan dengan cara menggoreskan koloni yang diambil dengan jarum ose pada medium padat BHMS mengandung protein dengan metode kuadran.

\section{Isolasi Bakteri Antagonis Asal Jaringan Tanaman Karet dan Rizosfer}

Isolasi bakteri antagonis diawali dengan pengambilan sampel jaringan tanaman karet yang berasal dari daun dan akar serta dari tanah sekitar rizosfer. Sampel daun tanaman karet diperkecil menjadi ukuran $1 \times 1 \mathrm{~cm}^{2}$ dan sampel akar dipotong-potong dengan panjang $1 \mathrm{~cm}$. Daun dan akar yang telah dipotong-potong tersebut dicuci dengan air, lalu ditimbang masing-masing seberat $1 \mathrm{~g}$. Sampel daun dan akar tersebut dimasukkan ke dalam erlenmeyer $100 \mathrm{~mL}$, lalu disterilisasi permukaannya dengan menggunakan alkohol $70 \%$ selama tiga menit, kemudian dibilas menggunakan akuades steril hingga aroma alkohol hilang, selanjutnya digerus menggunakan mortar dan diencerkan 100 kali menggunakan larutan fisiologis steril. Akar dan tanah asal rizosfer sebanyak $10 \mathrm{~g}$ direndam dalam $100 \mathrm{~mL}$ larutan fosiologis steril untuk mendapatkan suspensi tanah rizosfer, kemudian diencerkan 100 kali. Sebanyak $1 \mathrm{~mL}$ suspensi asal jaringan daun dan akar serta suspensi tanah rizosfer dari tiap pengenceran ditumbuhkan pada medium Nutrient Agar (NA) dengan metode agar tuang, lalu diinkubasi selama 24 jam pada suhu $30^{\circ} \mathrm{C}$ dalam inkubator. Pertumbuhan bakteri antagonis diamati dengan menghitung jumlah koloni yang terbentuk dan morfologi koloni. Koloni-koloni yang tumbuh selanjutnya dimurnikan pada medium NA dengan metode kuadran sebagai stok kerja.

\section{Uji Bakteri Antagonis Terhadap Bakteri Proteolitik}

Medium Nutrient Broth (NB) (3.0 g ekstrak daging sapi, $5.0 \mathrm{~g}$ pepton, $1000 \mathrm{~mL}$ akuades) steril disiapkan sebanyak $10 \mathrm{~mL}$ dalam tabung reaksi. Dengan menggunakan jarum ose, diambil 1 ose koloni murni setiap isolat (baik proteolitik maupun antagonis), diinokulasikan pada medium NB dalam tabung reaksi, kemudian diinkubasikan selama 24 jam pada suhu ruang. Setelah 24 jam, kepadatan sel bakteri dihitung menggunakan hemasitometer. Kepadatan sel bakteri setiap isolat ditetapkan pada $10^{6} \mathrm{sel} \mathrm{mL}^{-1}$ sebagai inokulan awal.

Uji daya hambat bakteri antagonis terhadap proteolitik dilakukan pada medium Nutrient Agar (NA). Cawan petri berisi medium NA diberi tanda dengan membagi area cawan sama luas sebanyak jumlah isolat bakteri antagonis. Dengan menggunakan mikropipet diambil $0.1 \mathrm{~mL}$ biakan bakteri proteolitik dari medium cair, lalu disebar menggunakan metode spread pada cawan petri. Kertas Whatman sebanyak tiga lapis berbentuk cakram berdiameter $7 \mathrm{~mm}$ dicelupkan ke dalam biakan cair bakteri antagonis menggunakan pinset steril, lalu 
diletakkan pada cawan petri yang telah disebar bakteri proteolitik. Semua bakteri antagonis disusun pada cawan petri yang telah mengandung bakteri proteolitik (Gambar 1), kemudian ditumbuhkan selama 24 jam pada suhu $30^{\circ} \mathrm{C}$ dalam inkubator. Diameter zona hambatan yang terbentuk di lingkaran kertas cakram diukur dengan menggunakan jangka sorong.

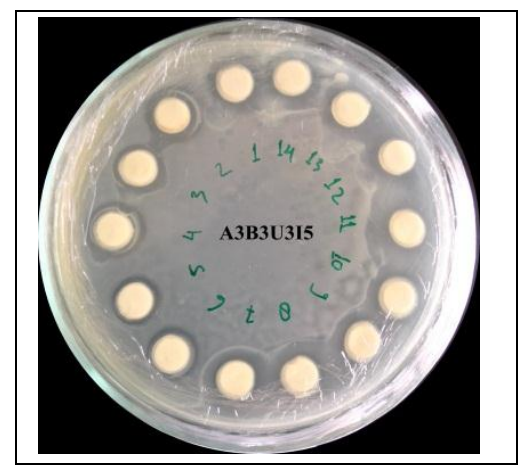

Gambar 1. Pengujian daya hambat bakteri antagonis (pada kertas cakram) terhadap bakteri proteolitik (pada medium NA).

\section{HASIL DAN PEMBAHASAN}

\section{Bakteri Proteolitik}

Dari 27 sampel bokar yang diisolasi, diperoleh 20 cawan petri yang ditumbuhi bakteri proteolitik dengan ciri terbentuknya zona jernih di sekitar koloni bakteri yang tumbuh. Rata-rata populasi bakteri proteolitik asal berbagai sumber dan morfologi koloni yang berhasil tumbuh disajikan pada Tabel 1 .

Pertumbuhan bakteri proteolitik sangat pesat yang dapat ditandai dengan waktu pertumbuhan yang relatif singkat, yakni dalam waktu 24 jam telah membentuk zona jernih di sekitar koloni. Zona jernih ini terbentuk karena bakteri yang tumbuh menghasilkan enzim protease, sehingga mampu menguraikan protein pada susu skim dalam medium tumbuh. Bakteri proteolitik mengkonsumsi sumber karbon sederhana yang terkandung di dalam medium. Karbon dalam konsentrasi rendah dan kadar protein tinggi merangsang pembentukan enzim protease. Semakin sedikit sumber karbonnya maka bakteri proteolitik akan menghasilkan enzim protease untuk dapat menguraikan protein (Assodeh dan Mussaabadi, 2012).

Tabel 1. Morfologi koloni bakteri proteolitik dengan berbagai sumber dan populasinya

\begin{tabular}{clccccc}
\hline No & $\begin{array}{c}\text { Sumber bakteri } \\
\text { proteolitik }\end{array}$ & $\begin{array}{c}\text { Populasi } \\
\left(\text { SPK } \mathrm{mL}^{-1}\right)\end{array}$ & $\begin{array}{c}\text { Bentuk Koloni } \\
\text { Dominan }\end{array}$ & $\begin{array}{c}\text { Bentuk Tepian } \\
\text { Koloni }\end{array}$ & $\begin{array}{c}\text { Bentuk Zona } \\
\text { Bening }\end{array}$ & Warna Koloni \\
\hline 1 & Lateks kebun & $1.1 \times 10^{5}$ & Oval & Membulat & Bulat & Putih \\
2 & Lateks kebun & $3.5 \times 10^{5}$ & Bulat & Membulat & Bulat & Putih \\
3 & Bokar petani & $41 \times 10^{5}$ & Bulat & Membulat & Bulat & Kekuningan \\
4 & Bokar petani & $13 \times 10^{5}$ & Bulat & Membulat & Bulat & Putih \\
5 & Bokar pabrik & $46 \times 10^{5}$ & Oval & Membulat & Bulat & Kekuningan \\
6 & Bokar pabrik & $54 \times 10^{5}$ & Bulat & Membulat & Bulat & Kekuningan \\
\hline
\end{tabular}

Berdasarkan bentuk koloni dominan, bentuk tepian koloni, bentuk zona bening dan warna koloni, diperoleh 6 karakter bakteri proteolitik dari 6 sumber berbeda (Tabel 1). Populasi bakteri proteolitik terendah $\left(1.1 \times 10^{5} \mathrm{SPK}\right.$ $\mathrm{mL}^{-1}$ ) dengan bentuk koloni oval, diikuti oleh bakteri proteolitik dengan bentuk koloni bulat $\left(3.5 \times 10^{5} \mathrm{SPK}\right.$ $\mathrm{mL}^{-1}$ ), keduanya berasal dari lateks kebun. Kepadatan populasi bakteri proteolitik asal lateks kebun yang lebih rendah dibandingkan bakteri proteolitik asal bokar petani dan bokar tersimpan di pabrik pengolahan karet dikarenakan lateks asal kebun relatif belum terkontaminasi bakteri. Populasi bakteri proteolitik terbanyak (54 x $10^{5}$ SPK $\mathrm{mL}^{-1}$ ) didapatkan pada bokar simpanan pabrik. Makin tinggi populasi bakteri proteolitik, perombakan protein yang merupakan komponen utama getah karet makin aktif yang berakibat pada pelepasan gas hidrogen sulfida dan amoniak ke udara yang menimbulkan bau tidak sedap. Bokar pabrik merupakan getah karet dalam penyimpanan waktu terlama dibandingkan lateks kebun dan bokar dari penyimpanan petani. Dengan bertambahnya waktu penyimpanan bokar, populasi bakteri proteolitik meningkat dan aktivitas protease juga meningkat. Sejalan dengan penelitian Purwati et al. (2011) bahwa dengan bertambahnya waktu, kadar protein larut hasil hidrolisis protease makin meningkat. Demikian pula Zilda et al. (2012) menyatakan bahwa aktivitas enzim protease meningkat dengan meningkatnya waktu.

Luasnya zona jernih yang terbentuk di sekitar koloni menunjukkan perbedaan kemampuan bakteri proteolitik dalam merombak protein. Hasil pengamatan secara visual menunjukkan bahwa masing-masing koloni bakteri proteolitik memiliki zona bening yang berbeda luasnya. Badriyah dan Ardyati (2013) menyatakan semakin besar kemampuan bakteri proteolitik dalam menghasilkan enzim protease maka zona bening yang terbentuk semakin luas.

Setelah dilakukan pemurnian isolat, diperoleh 2 isolat bakteri proteolitik asal lateks kebun, 4 isolat asal bokar petani, dan 8 isolat bakteri proteolitik asal bokar pabrik pengolahan karet. Total isolat bakteri proteolitik yang diuji dengan bakteri antagonis sebanyak 14 isolat.

\section{Bakteri Antagonis}

Dari eksplorasi bakteri antagonis asal jaringan akar dan daun tanaman karet dan rizosfer, didapatkan 11 cawan petri dari 15 sampel yang diisolasi yang ditumbuhi bakteri yang diharapkan memiliki sifat antagonis terhadap bakteri 
proteolitik. Adapun sumber isolat, populasi dan morfologi koloni bakteri antagonis disajikan pada Tabel 2.

Berdasarkan sifat morfologis bentuk koloninya, semua koloni memiliki kemiripan kecuali pada cawan dengan kode $\mathrm{A}_{2} \mathrm{U}_{2}$ yang memiliki tepian koloni bergelombang. Jumlah koloni bakteri bervariasi dari terendah pada isolat asal daun dengan kode isolat $\mathrm{D}_{1} \mathrm{U}_{1}$, yaitu $1.2 \times 10^{3} \mathrm{SPK} \mathrm{mL}^{-1}$ dan tertinggi pada isolat yang berasal dari tanah sekitar rizosfer dengan kode $\mathrm{R}_{2} \mathrm{U}_{1}$ dengan kepadatan mencapai $27 \times 10^{3} \mathrm{SPK} \mathrm{mL}^{-1}$. Populasi bakteri antagonis asal rizosfer lebih tinggi dibandingkan populasi bakteri antagonis asal daun dan akar. Meskipun menurut Hallmann dan Berg (2006) bakteri endofitik asal jaringan daun segar kerapatan populasinya rendah dengan rata-rata hanya $10^{3} \mathrm{SPK} \mathrm{mL}^{-1}$, namun pada penelitian ini populasi bakteri endofitik pada daun tidak selalu lebih rendah dibandingkan pada akar. Perbedaan populasi bakteri antagonis dari ketiga sumber diduga disebabkan eksudat yang dikeluarkan baik melalui daun maupun akar tanaman disukai bakteri, sehingga eksudat tersebut menarik bakteri filosfer dan rizosfer untuk mengkolonisasi jaringan daun dan rizosfer tanaman (Pinton et al., 2007).

Tabel 2. Morfologi koloni bakteri antagonis dari berbagai sumber dan populasinya

\begin{tabular}{ccccccc}
\hline No & Sumber & Kode cawan & $\begin{array}{c}\text { Populasi } \\
\left(\mathrm{spk} \mathrm{mL} \mathrm{m}^{-1}\right.\end{array}$ & $\begin{array}{c}\text { Bentuk Koloni } \\
\text { Dominan }\end{array}$ & Bentuk Tepian Koloni & Warna Koloni \\
\hline 1 & Daun & $\mathrm{D}_{1} \mathrm{U}_{1}$ & $1.2 \times 10^{3}$ & Bulat & Membulat & Putih \\
2 & Daun & $\mathrm{D}_{1} \mathrm{U}_{2}$ & $1.8 \times 10^{3}$ & Bulat & Membulat & Putih \\
3 & Daun & $\mathrm{D}_{2} \mathrm{U}_{1}$ & $7.0 \times 10^{3}$ & Bulat & Membulat & Putih \\
4 & Daun & $\mathrm{D}_{2} \mathrm{U}_{2}$ & $6.0 \times 10^{3}$ & Bulat & Membulat & Putih \\
5 & Akar & $\mathrm{A}_{1} \mathrm{U}_{1}$ & $2.8 \times 10^{3}$ & Bulat & Membulat & Putih \\
6 & Akar & $\mathrm{A}_{1} \mathrm{U}_{2}$ & $1.9 \times 10^{3}$ & Bulat & Membulat & Putih \\
7 & Akar & $\mathrm{A}_{2} \mathrm{U}_{2}$ & $17 \times 10^{3}$ & Tidak Beraturan & Bergelombang & Putih \\
8 & Rizosfer & $\mathrm{R}_{1} \mathrm{U}_{1}$ & $5.2 \times 10^{3}$ & Bulat & Membulat & Putih \\
9 & Rizosfer & $\mathrm{R}_{1} \mathrm{U}_{2}$ & $2.9 \times 10^{3}$ & Bulat & Membulat & Putih \\
10 & Rizosfer & $\mathrm{R}_{2} \mathrm{U}_{1}$ & $27 \times 10^{3}$ & Bulat & Membulat & Putih \\
11 & Rizosfer & $\mathrm{R}_{2} \mathrm{U}_{2}$ & $15 \times 10^{3}$ & Bulat & Membulat & Putih \\
\hline
\end{tabular}

Setelah dilakukan pemurnian, didapatkan 14 isolat dari 11 cawan petri (Tabel 2) yang ditumbuhi bakteri antagonis. Diperoleh 3 isolat dari cawan $\mathrm{D}_{2} \mathrm{U}_{1}$ (isolat $\mathrm{D}_{2} \mathrm{U}_{1} \mathrm{~B}_{1}, \mathrm{D}_{2} \mathrm{U}_{1} \mathrm{~B}_{2}$, dan $\mathrm{D}_{2} \mathrm{U}_{1} \mathrm{~B}_{3}$ ) dan 2 isolat dari cawan $\mathrm{D}_{2} \mathrm{U}_{2}$ (isolat $\mathrm{D}_{2} \mathrm{U}_{2} \mathrm{~B}_{1}$ dan $\mathrm{D}_{2} \mathrm{U}_{2} \mathrm{~B}_{2}$ ) serta masing-masing 1 isolat dari cawan lainnya, sehingga total isolat bakteri antagonis yang diujikan sebanyak 14 isolat.

\section{Daya Hambat Bakteri Antagonis}

Isolat yang memiliki potensi sebagai bakteri antagonis terhadap bakteri proteolitik ditunjukkan dengan kemampuannya membentuk zona bening atau zona hambat. Kemampuan bakteri antagonis dalam menghambat bakteri proteolitik disajikan pada Tabel 3 . Berdasarkan Tabel 3, sebagian besar isolat bakteri antagonis mampu membentuk zona hambat pada medium yang telah ditumbuhi bakteri proteolitik. Kemampuan bakteri antagonis sangat baik digunakan untuk menghambat pertumbuhan bakteri proteolitik. Dari 196 pasangan yang diujikan (14 bakteri antagonis terhadap 14 bakteri proteolitik), hanya 5 pasangan yang tidak bersifat antagonis. Kemampuan isolat bakteri antagonis yang diperoleh dari penelitian ini tidak efektif hanya terhadap beberapa isolat bakteri proteolitik saja. Isolat bakteri antagonis $\mathrm{R}_{1} \mathrm{U}_{2}$ tidak memiliki daya hambat terhadap isolat bakteri proteolitik $A_{1} B_{2}$ dan $A_{2} B_{1}$. Isolat bakteri antagonis $\mathrm{D}_{2} \mathrm{U}_{1} \mathrm{~B}_{3}$ tidak efektif terhadap isolat bakteri proteolitik $\mathrm{A}_{2} \mathrm{~B}_{3}$ dan $\mathrm{A}_{3} \mathrm{~B}_{4}$. Isolat bakteri antagonis $\mathrm{D}_{2} \mathrm{U}_{1} \mathrm{~B}_{2}$ tidak memiliki daya hambat terhadap bakteri proteolitik $\mathrm{A}_{3} \mathrm{~B}_{6}$. Tidak mampunya ketiga bakteri antagonis tersebut menghambat 5 isolat bakteri proteolitik diduga karena bakteri proteolitik memiliki kemampuan yang lebih kuat dalam berkompetisi dan tidak mampu dihambat oleh zat penghambat yang dieksudasi oleh bakteri antagonis. Secara umum, diketahui bahwa kemampuan 14 isolat bakteri antagonis asal jaringan tanaman karet dan rizosfer akar dalam emnghambat bakteri proteolitk sebesar $97.44 \%$. Bakteri antagonis dengan spektrum yang luas seperti yang ditemukan dalam penelitian ini merupakan persyaratan untuk dikembangkan sebagai agensia pengendali hayati patogen (Djatmiko et al., 2007), termasuk pengendali bakteri perombak lateks. 
Tabel 3. Daya hambat bakteri antagonis terhadap bakteri proteolitik

\begin{tabular}{|c|c|c|c|c|c|c|c|c|c|c|c|c|c|c|}
\hline \multirow{2}{*}{$\begin{array}{c}\text { Bakteri } \\
\text { Proteolitik }\end{array}$} & \multicolumn{14}{|c|}{ Diameter zona hambat bakteri antagonis ${ }^{*}(\mathrm{~mm})$ terhadap bakteri proteolitik } \\
\hline & $\mathrm{D}_{1} \mathrm{U}_{2}$ & $\mathrm{D}_{1} \mathrm{U}_{1}$ & $\mathrm{D}_{2} \mathrm{U}_{1} \mathrm{~B}_{2}$ & $\mathrm{D}_{2} \mathrm{U}_{2} \mathrm{~B}_{2}$ & $\mathrm{D}_{2} \mathrm{U}_{2} \mathrm{~B}_{1}$ & $\mathrm{D}_{2} \mathrm{U}_{1} \mathrm{~B}_{1}$ & $\mathrm{D}_{2} \mathrm{U}_{1} \mathrm{~B}_{3}$ & $\mathrm{~A}_{1} \mathrm{U}_{1}$ & $\mathrm{~A}_{1} \mathrm{U}_{2}$ & $\mathrm{~A}_{2} \mathrm{U}_{2}$ & $\mathrm{R}_{1} \mathrm{U}_{1}$ & $\mathrm{R}_{1} \mathrm{U}_{2}$ & $\mathrm{R}_{2} \mathrm{U}_{1}$ & $\mathrm{R}_{2} \mathrm{U}_{2}$ \\
\hline $\mathrm{A}_{1} \mathrm{~B}_{2}$ & 10.9 & 10.7 & 10.8 & 10.6 & 9.9 & 10.2 & 10.2 & 9.3 & 9.4 & 10.7 & 11.7 & 13.7 & 12.7 & 11.7 \\
\hline $\mathrm{A}_{1} \mathrm{~B}_{2}$ & 11.2 & 10.1 & 10.3 & 10.5 & 9.6 & 8.9 & 9.8 & 10.4 & 13.7 & 10.5 & 9.1 & $7.0^{*}$ & 10.2 & 10.2 \\
\hline $\mathrm{A}_{2} \mathrm{~B}_{1}$ & 13.1 & 13.5 & 11.2 & 11.7 & 11.9 & 9.3 & 9.6 & 13.7 & 12.2 & 13.3 & 12.7 & $7.0^{*}$ & 12.7 & 11.2 \\
\hline $\mathrm{A}_{2} \mathrm{~B}_{2}$ & 10.2 & 10.2 & 9.0 & 7.8 & 10.2 & 9.2 & 10.2 & 12.2 & 11.2 & 11.7 & 11.2 & 12.4 & 10.7 & 9.2 \\
\hline $\mathrm{A}_{2} \mathrm{~B}_{3}$ & 10.2 & 11.7 & 11.4 & 11.1 & 11.3 & 12.2 & $7.0^{*}$ & 9.9 & 11.8 & 11.3 & 10.7 & 9.3 & 10.7 & 9.8 \\
\hline $\mathrm{A}_{2} \mathrm{~B}_{4}$ & 10.2 & 10.7 & 11.5 & 11.7 & 12.7 & 12.5 & 11.7 & 11.5 & 10.2 & 10.5 & 10.3 & 10.5 & 9.9 & 10.3 \\
\hline $\mathrm{A}_{3} \mathrm{~B}_{1}$ & 9.5 & 8.9 & 10.2 & 8.5 & 8.5 & 8.7 & 9.7 & 9.5 & 9.3 & 11.2 & 9.2 & 8.9 & 8.9 & 11.5 \\
\hline $\mathrm{A}_{3} \mathrm{~B}_{2}$ & 11.2 & 11.2 & 13.2 & 12.5 & 11.5 & 11.4 & 10.2 & 9.8 & 9.8 & 10.2 & 10.5 & 11.5 & 12.2 & 12.2 \\
\hline $\mathrm{A}_{3} \mathrm{~B}_{3}$ & 11.2 & 11.2 & 9.9 & 10.2 & 10.4 & 11.5 & 10.5 & 12.5 & 12.7 & 10.2 & 12.7 & 10.7 & 11.7 & 11.6 \\
\hline $\mathrm{A}_{3} \mathrm{~B}_{4}$ & 11.1 & 10.2 & 9.3 & 9.3 & 8.9 & 8.7 & $7.0^{*}$ & 9.8 & 9.8 & 10.4 & 10.2 & 9.9 & 10.5 & 10.2 \\
\hline $\mathrm{A}_{3} \mathrm{~B}_{5}$ & 12.2 & 11.2 & 12.5 & 11.5 & 12.5 & 11.3 & 11.2 & 9.5 & 10.2 & 11.2 & 11.2 & 12.1 & 11.2 & 12.2 \\
\hline $\mathrm{A}_{3} \mathrm{~B}_{6}$ & 12.2 & 13.7 & 11.3 & 12.2 & 12.1 & 10.2 & 8.9 & 9.2 & 10.2 & 10.5 & 10.8 & 11.2 & 11.3 & 11.2 \\
\hline $\mathrm{A}_{3} \mathrm{~B}_{7}$ & 13.1 & 13.4 & 13.3 & 13.3 & 11.4 & 12.2 & 12.5 & 14.2 & 13.3 & 13.4 & 13.2 & 14.2 & 13.2 & 12.2 \\
\hline $\mathrm{A}_{3} \mathrm{~B}_{8}$ & 9.5 & 12.5 & $7.0^{*}$ & 11.5 & 15.7 & 12.9 & 11.2 & 13.7 & 13.3 & 13.0 & 14.2 & 12.0 & 11.1 & 11.7 \\
\hline Rata-rata & 11.12 & 11.37 & 10.27 & 10.88 & 11.18 & 10.65 & 8.97 & 11.08 & 11.22 & 11.29 & 10.67 & 7.93 & 11.14 & 11.08 \\
\hline
\end{tabular}

Berdasarkan Tabel 3 terdapat 10 isolat yang mampu menghambat semua isolat bakteri proteolitik. Dari 10 isolat yang memiliki potensi menghambat bakteri proteolitik diperoleh 2 isolat bakteri dengan diameter zona hambat terbesar, yakni isolat $\mathrm{D}_{1} \mathrm{U}_{1}$ dan $\mathrm{A}_{2} \mathrm{U}_{2}$. Isolat $\mathrm{D}_{1} \mathrm{U}_{1}$ membentuk diameter zona hambat rata-rata $11.37 \mathrm{~mm}$ dan isolat $\mathrm{A}_{2} \mathrm{U}_{2}$ dengan diameter zona hambat rata-rata 11.29 mm. Isolat $\mathrm{D}_{1} \mathrm{U}_{1}$ berasal dari jaringan daun tanaman karet. sedangkan isolat $\mathrm{A}_{2} \mathrm{U}_{2}$ berasal dari jaringan akar tanaman karet. Dengan demikian kedua bakteri yang berpotensi dikembangkan sebagai pengendali proteolitik bokar adalah bakteri endofitik asal jaringan tanaman karet.

Menurut Strobel dan Daisy (2003) terbentuknya zona hambat menandakan bahwa bakteri antagonis tersebut menghasilkan antibiotik. Antibiotik digolongkan sebagai metabolit sekunder yang dihasilkan oleh bakteri endofitik dan antagonis dalam jalur metabolisme dan oleh enzim yang tidak diperlukan untuk pertumbuhan dan pemeliharaan sel tumbuhan. Dengan adanya dugaan bakteri antagonis mampu menghasilkan antibiotik maka mekanisme terpenting dari kerja antibiotik terhadap sel bakteri adalah menghambat sintesa protein dan asam nukleat oleh bakteri proteolitik. Selain mekanisme tersebut aktivitas antibiotik juga meliputi perusakan dan penghambatan pembentukan dinding sel. perubahan permeabilitas sel target dan penghambatan kerja enzim yang berperan dalam pertumbuhan bakteri (Tasnim et al., 2011).

\section{SIMPULAN}

Dari hasil penelitian ini diperoleh dua isolat bakteri yang berpotensi dikembangkan sebagai bakteri antagonis terhadap bakteri proteolitik perombak bahan olahan karet (bokar) dalam proses penyimpanan. Kedua bakteri antagonis tersebut adalah isolat dengan kode $\mathrm{D}_{1} \mathrm{U}_{1}$ yang berasal dari jaringan daun tanaman karet dan isolat $\mathrm{A}_{2} \mathrm{U}_{2}$ dari jaringan akar tanaman karet. yang menghasilkan diameter zona hambat berturut-turut 11.37 dan $11.29 \mathrm{~mm}$.

\section{UCAPAN TERIMA KASIH}

Ucapan terima kasih disampaikan kepada Gabungan Pengusaha Karet Indonesia (GAPKINDO) cabang Sumatera Selatan yang telah mendanai penelitian ini melalui kerjasama yang dilegalkan dengan SPK no. 344/SK-PEN/GAP/VI/2014.

\section{DAFTAR PUSTAKA}

Assodeh, A. and H.M. Mussaabadi. 2012. Purification and characterization of thermostable neuthrophilic metalloprotease from Pseudomonas sp. DR89. Iranian J. of Biotech., 10: 120-128.

Badriyah, T. dan Ardyati. 2013. Deteksi aktivitas proteolitik isolat bakteri asal ampas tahu pada substrat bekatul. J. Biotropika, 1: 109-113.

Direktorat Jenderal Perkebunan. 2012. Luas areal karet menurut propinsi di seluruh Indonesia. Statistik Perkebunan Tahun 2009 - 2012. Jakarta.

Djatmiko, H., T. Arwiyanto, B. Hadisutrisno dan B. Sunarminto. 2007. Potensi tiga genus bakteri dari tiga rizosfer tanaman sebagai agensia pengendali hayati penyakit lincat. Jurnal Ilmu-Ilmu Pertanian Indonesia, 9: 40 - 47 .

Elfita, Muharni, Munawar, and S. Aryani. 2012. Secondary metabolite from endophytic fungi Aspergillus niger of the stem bark of Kandis Gajah (Garcinia griffithii). Indo. J. Chem., 12: 195-200.

Estuningsih, S., Muharni, dan M. Rynanda. 2012. Isolasi dan identifikasi bakteri hidrokarbon di sekitar rizosfer rumput belulang (Eleusine Indica (L.) Gaertn) yang berperan dalam fitoremediumsi 
limbah minyak bumi. J. Penelitian Sains, 15: $40-$ 43.

Gofar, N., H. Widjajanti, dan N.L.P.S. Ratmini. 2012. Populasi bakteri penambat nitrogen dan pelarut fosfat pada rizosfer tanaman pangan di lahan. Prosiding Seminar Perhepi Pengelolaan Agribisnis Pangan pada Korporasi Lahan Suboptimal. ISBN: 978-979-8420-12-2.

Gofar, N. 2013. Synergism of wild grass and hydrocarbonoclastic bacteria in petroleum biodegradation. J. Trop. Soils., 18: 161-168.

Hallmann, J. and G. Berg. 2006. Spectrum and Population Dynamics of Bacterial Root Endophytes. Microbial Roots Endophytes. Springer-Verlag Berlin.

Hidayah, N. dan T. Yulianti. 2008. Peranan bakteri endofit dalam reaksi ketahanan tanaman terhadap patogen. J. Pengendalian Hayati, 1: 88-93.

Munawar, P. Aditiawati, and D.I. Astuti. 2012. Sequential isolation of saturated. aromatic. resinic and asphaltic fractions degrading bacteria from oil contaminated soil in South Sumatra. Makara Journal of Science, 16: 58-64.
Pinton, R., Z. Varananni, and P. Namipieri. 2007. The Rhizosfer: Biochemistry and Organic Subtances at the Soil. Plant Interface $2^{\text {nd }}$. CRC. New York.

Purwati, S., R.S. Soetopo, dan T. Idiyanti. 2011. Aplikasi protease dan pengaruh suhu pada asidifikasi digestasi anaerobik dua-tahap lumpur ipal biologi industri kertas. J. Selulosa, 1: 20-30.

Strobel, G. and B. Daisy. 2003. Bioprospecting for microbial endophytes and their natural products: Microbiology and Molecular Biology Reviews. $J$. Microbiol, 67: 491-502.

Tasnim, S, K. Retno, dan N.P.A. Astiti. 2011. Efektifitas daya hambat bakteri Streptomyces sp. terhadap Erwinia sp. penyebab penyakit busuk rebah pada tanaman lidah buaya (Aloe Barbadensis Mill). J. Simbiosis, I: 21-27.

Zilda, D.S., E. Harmayani, J. Widada, W. Asmara, H.E. Irianto, G. Patantis, and Y.N. Fawzya. 2012. Screening of thermostable protease producing microorganisms isolated from Indonesian hotspring. Squalen, 7: 105-114. 